\title{
Mass media image of selected instruments of economic develepment
}

\section{Ladislav Kruliš ${ }^{1}$}

\begin{abstract}
The goal of this paper is twofold. Firstly, two instruments of economic development - investment incentives and cluster initiatives - were compared according to the frequency of their occurrence in selected mass media sources in the Czech Republic in the periods 2004-2005 and 2011-2012. Secondly, the mass media image of these two instruments of economic development was evaluated with respect to the frames deductively constructed from literature review. The findings pointed out a higher occurrence of the mass media articles/news dealing with investment incentives. These articles/news were, additionally, more controversial and covered a wider spectrum of frames. Politicians were a relatively more frequent type of actors who created the media message from the articles/news. On the contrary, the mass media articles/news concerning cluster initiatives typically created the frame of positive effects of clusters. The messages were told either by economic experts or by public authority representatives who were closely connected with cluster initiatives. Spatial origin of these messages was rather limited. The definitional vagueness, intangible and uncontroversial nature of cluster initiatives restrained their media appeal.
\end{abstract}

Key words: Mass media, image, framing, agenda-setting, investment incentives, cluster initiatives, Czech Republic

\section{INTRODUCTION}

Modern society is hugely influenced by mass media. Mass media choose and formulate messages, highlight some messages while suppressing others. Peoples' attitudes are, consequently, shaped by mass media (see, e.g., Lecheler \& de Vreese 2012, Wimmer \& Dominick 2011, Horváth \& Machyniak 2014). De Vreese (2005) claims that mass media may even change attitudes of a whole society. Additionally, the importance of mass media is increasing in the recent era of globalization because time-space compression enables messages to reach more and more listeners (see, e.g., Morley \& Robins 1995). Not surprisingly, mass media messages are of high interest for both, researchers and politicians (see, e.g., Scheufele \& Iyengar 2014, de Vreese, Peter \& Semetko 2001, de Vreese 2012).

The mass media research was embedded in various thematic domains and methodological approaches. Hence, Matthes and Kohring (2008) analyzed the mass media messages concerning attitudes to economic and societal impacts 1 Ladislav Kruliš, Tomas Bata University in Zlin, Faculty of Management and Economics, 76001 Zlin, Mostní 5139, Czech Republic 
of biotechnologies; Lecheler and de Vreese (2012) the mass media messages concerning attitudes to EU enlargement; de Vreese, Peter and Semetko (2001), de Vreese (2005) the mass media messages concerning attitudes to Euro adoption; Soroka, Maioni and Martin (2013) the mass media messages concerning attitudes to health-care quality. Note that all the papers were closely related to the questions relevant for policy formulation. Mass media messages may have, in this regard, a significant influence on final decisions, even despite their discrepancy with scientific knowledge. It is highly useful, therefore, to find and explain the mass media image of the thematic domains that are subjects to political decisionmaking. This paper is focused on this issue using two instruments of economic development as the domain of further analysis - investment incentives and cluster initiatives.

Agenda-setting, priming and framing are prominent theoretical and methodological concepts for analyzing mass media image of various thematic domains. Agenda-setting and priming uphold exposure of people to mass media messages while framing emphasizes the way how listeners receive them. This paper is embedded in both, the agenda-setting and framing concepts. Both, occurrence of the two instruments of economic development in mass media and the content of mass media messages concerning with these two instruments are analyzed. Thus, the goal of this paper is twofold. Firstly, investment incentives and cluster initiatives are compared according to the frequency of their occurrence in selected mass media sources in the Czech Republic in the periods 2004-2005 and 2011-2012. Secondly, the mass media image of investment incentives and cluster initiatives is evaluated with respect to the frames deductively constructed from a literature review. Note that investment incentives became an important instrument of economic development in the Czech Republic at the turn of the $21^{\text {st }}$ century and that the interest in cluster initiatives was sparked before the Czech Republic's EU accession in 2004.

The remainder of this paper is structured as follows: the first two sections provide a literature review related to agenda setting and framing and investment incentives and cluster initiatives respectively. Additionally, the frames used for further analysis of media image of investment incentives and cluster initiatives in Czech media are defined in the second section. The third section introduces the methodology used in order to draw conclusions. The fourth section summarizes empirical findings and these findings are further discussed in the fifth section. The last section concludes this study. 


\section{AGENDA SETTING, PRIMING AND FRAMING}

Agenda-setting, priming and framing have become prominent theoretical and methodological concepts for analyzing mass media image of various thematic domains. Agenda-setting and priming emphasize characteristics of particular messages. The agenda-setting concept claims that higher exposure of people to messages increases importance of them (see, e.g., Scheufele \& Iyengar 2014). Hence, there is an association between the importance of particular messages in mass media and in peoples' perception (see, e.g., Scheufele \& Tewksbury 2007). Highly important messages are better remembered, evoked and used (see, e.g., Entman 1993). The priming concept may be understood as an extension of agenda-setting. The messages that are often repeated in mass media become standards of interpretation. Mass media content may be subsequently compared against these standards (see, e.g., Scheufele \& Tewksbury 2007).

Framing differs from agenda-setting and priming through its emphasis on the way how listeners receive mass media messages (see table 1 for differences between agenda-setting and priming on one hand and framing on the other). However, a clear definition of the framing concept is missing. Borah (2011), Scheufele and Iyengar (2014) distinguish, in this regard, two theoretical approaches:

- The sociological approach regards communication through words, pictures, phrases, or presentations as the cornerstone of framing. Communication makes it easier to interpret mass media messages as frames. Frames help to organize large amount of information that people are not able to understand at once. Frames come as organizing ideas, designed to integrate the content of mass media messages in a story understandable to the widest possible audience (see, e.g., de Vreese 2005).

- The psychological approach upholds the importance of processes that make individuals' frames from mass media messages. In this regard, the seminal work by Kahneman and Tversky (1984) showed that the way how information had been presented led to different decisions (see, also, Lecheler \& de Vreese 2012 for this conclusion). Generally, a number of peoples' characteristics, e.g. education and experience, age, sex, political engagement and others, influence individuals' frames (see, e.g., Borah 2011, Scheufele \& Tewksbury 2007, Lecheler \& de Vreese 2012, Soroka, Maioni \& Martin 2013, Entman 1993). These characteristics ought to be, therefore, considered when interpreting results (see, e.g., Lecheler \& de Vreese 2012).

Note that the sociological approach typically analyzes mass media content while 
the psychological approach is more focused on individuals and their ways of perceiving, organizing and interpreting frames (see, e.g., Borah 2011, de Vreese, Peter \& Semetko 2001, de Vreese 2005).

Table 1: Comparison of agenda-setting, priming and framing

\begin{tabular}{|l|l|}
\hline \multicolumn{1}{|c|}{ Agenda-setting and priming } & \multicolumn{1}{c|}{ Framing } \\
\hline $\begin{array}{l}\text { Media choose messages for commu- } \\
\text { nication. Hence, media tell people } \\
\text { about which messages they ought to } \\
\text { think. }\end{array}$ & $\begin{array}{l}\text { Framing is interested in the question } \\
\text { how people store and interpret media } \\
\text { messages in the form of various cog- } \\
\text { nitive schemas. }\end{array}$ \\
\hline $\begin{array}{l}\text { Agenda-setting and priming emphasi- } \\
\text { ze the peoples' ability to evoke media } \\
\text { messages in their memories. Thus, } \\
\text { accessibility of media messages in } \\
\text { memories is crucial. }\end{array}$ & $\begin{array}{l}\text { Framing emphasizes the peoples' } \\
\text { ability to link media messages with } \\
\text { some cognitive schemas stored in } \\
\text { their memories. }\end{array}$ \\
\hline $\begin{array}{l}\text { Agenda-setting and priming have } \\
\text { impact on all people. Peoples' skills } \\
\text { and abilities are of lower importance } \\
\text { in this regard. }\end{array}$ & $\begin{array}{l}\text { Framing is highly dependent on peo- } \\
\text { ples' skills and abilities to store and } \\
\text { interpret cognitive schemas. Thus, } \\
\text { peoples' characteristics are crucial in } \\
\text { the framing concept. }\end{array}$ \\
\hline
\end{tabular}

Source: own elaboration based on Scheufele and Iyengar (2014), Scheufele and Tewksbury (2007), Borah (2011)

Recent mass media research increasingly emphasizes the importance of the framing concept (see, e.g., Borah 2011, de Vreese, Peter \& Semetko 2001, Scheufele \& Iyengar 2014). Various methodological approaches are used in order to construct frames. Inductive approaches construct frames directly from the content of mass media messages (see, e.g., Borah 2011, Matthes \& Kohring 2008). Deductive approaches construct frames before the mass media analysis. A review of relevant theories may be used in this regard (see, e.g., de Vreese 2005, de Vreese, Peter \& Semetko 2001, Matthes \& Kohring, 2008). Note that the latter approach is preferred in the mass media research. Additionally, two types of frames are distinguished. Specific frames adapted to a particular situation are able to address unique features of the situation better than general frames. However, general frames (e.g., conflict, moral aspects, or economic impacts) are more suitable when comparing different thematic domains (see, e.g., de Vreese 2005, de Vreese, Peter \& Semetko 2001). Finally, note the changing nature of 
frames in time (see, e.g., Matthes \& Kohring 2008, Lecheler \& de Vreese 2012) and the importance of actors who create frames, e.g. political and societal elites, donators, lobbyists and others (see, e.g., Borah 2011, de Vreese 2005, Entman 1993, Scheufele \& Tewksbury 2007).

\section{INVESTMENT INCENTIVES, CLUSTER INITIATIVES - FRAMES}

A vast body of literature was devoted to instruments of economic development. These include also investment incentives and clusters. Investment incentives may be understood as government measures - fiscal, financial and non-financial - aspiring to influence investors' location decision (see, e.g., Ginevičius \& Šimelyte 2011, Globerman \& Shapiro 1999, Burger, Jaklič \& Rojec 2012, Hayter 1997). Burger, Jaklič and Rojec (2012), Blomström, Kokko and Mucchielli (2003) explain the rationale of investment incentives through the positives induced by new investments. The positives may involve newly created jobs, gross added value, increasing export and tax revenues, new knowledge inflow and spillovers resulting into higher productivity and competitiveness of local economy (see, also e.g., Dicken 2003, Nafziger 2006). Note that close links to local economy, such as cooperation with local firms, improve the positive effects of new investments (see, e.g., Ginevičius \& Šimelyte 2011).

However, several negative aspects of investment incentives are mentioned in scholarly literature as well. Firstly, costs of investment incentives, including transfer pricing, may be higher than positive effects induced by new investments (see, e.g., Burger, Jaklič \& Rojec 2012, Hayter 1997, Ginevičius \& Šimelyte 2011). Secondly, positive effects from new investments are reduced when links to local economy are not created. Multiplier effects are missing in this case. Similarly, low-technology investments decrease positive effects from new investments (see, e.g., Ginevičius \& Šimelyte 2011, Blomström, Kokko \& Mucchielli 2003). Thirdly, there is a thread of investors' rent-seeking behaviour. Thus, they may leave the country after exhausting investment incentives, for example (see, e.g., Blomström, Kokko \& Mucchielli 2003, Ginevičius \& Šimelyte 2011, Burger, Jaklič \& Rojec 2012). Fourthly, investment incentives distort the efficiency of market forces. Hence, the firms not supported by investment incentives are disadvantaged in market competition. The market distortion is often discussed with respect to the disadvantageous position of some types of firms, especially small and medium firms and local firms respectively (Blomström, Kokko \& Mucchielli 2003).

Investment incentives are further related to some spatial issues. Firstly, territorial competition for new investments is increasingly fierce in globally 
interlinked markets (see, e.g., Ginevičius \& Šimelyte 2011, Burger, Jaklič \& Rojec 2012, Hayter 1997). Consequently, a high number of countries offer a package of investment incentives in order to attract new investments (see, e.g., Globerman \& Shapiro 1999). Blomström, Kokko and Mucchielli (2003), Dicken (2003) even claim that territories can hardly stay outside the investment incentive competition scheme if they try to attract new investments. Secondly, investment incentives might be used as an instrument for achieving balanced territorial development (see, e.g., Burger, Jaklič \& Rojec 2012). National governments prefer, in this regard, location of new investments in lagging regions (see, e.g., Hayter 1997).

Despite no unanimously accepted definition, clusters are a politically influential concept. Porter (2000) claims that "clusters are geographical concentration of interconnected companies, specialized suppliers, service providers, firms in related industries, and associated institutions (e.g. universities, standard agencies, trade associations)". Theories emphasize several benefits of clusters (see, e.g., Porter 2000, Waxell \& Malmberg 2007, Bathelt, Malmberg \& Maskell 2004, Maskell 2001, Hájek, Novosák \& Hovorková 2011):

- Geographic concentration of interconnected companies, specialized suppliers, service providers and associated institutions offer an easier access to specialized inputs and qualified labour-force. Clusters, moreover, attract additional firms increasing the quality of specialized inputs.

- Clusters facilitate and enhance information, knowledge and innovation spillovers among cooperating partners. Spatial proximity, specialized knowledge and trust improve the quality of spillovers in clusters. Consequently, clusters are better prepared to identify and capitalize market opportunities.

- A better match of complementary competence among their members might be achieved in clusters. This involves product chain management, marketing and image building, cost savings, education, lobbying and others.

- Clusters support performance management of their members through benchmarking. Hence, cluster members compare themselves with others revealing their strengths and weaknesses for further improvements. Hence both, cooperation and competition in clusters increase competitiveness of their members.

Altogether, a positive impact of clusters on new job creation, gross added value, export and tax revenues, innovations and the quality of human capital is substantiated from a theoretical point of view. Note that a number of studies (see, 
e.g., Nuur \& Laestadius 2010, Tödtling \& Trippl 2005) showed the relevance of cluster development for various types of regions, including lagging regions. Cluster development is, therefore, readily supported by government initiatives in various spatial contexts. Brown and McNaughton (2003) even claim that cluster development is the latest panacea in government initiatives to encourage home-based competitive advantage. However, cluster theory emphasizes also the opposite side of the coin. Firstly, Martin and Sunley (2003) point out the vagueness of the definition of the term itself. This vagueness concerns with both, the spatial level of and nature of links in clusters. Consequently, difficulties how to measure and operationalize cluster initiatives arises and the way how to select clusters for support is not clear. Secondly, Martin and Sunley (2003) claim that cluster initiatives may be implemented also outside the cluster concept, thus evoking the question whether cluster initiatives are not motivated only by public subsidies. In this case, effects of cluster initiatives are questioned. Moreover, cluster initiatives, similarly to investment incentives, distort the efficiency of market forces. Following the above mentioned considerations six frames related to investment incentives and cluster initiatives were defined. Table 2 reviews the frames including their short description. The frames were used for further analysis of media image of investment incentives and cluster initiatives in Czech media.

Table 2: Investment incentives and cluster initiatives - frames

\begin{tabular}{|l|l|}
\hline Frames & Description \\
\hline Explanation & $\begin{array}{l}\text { The distinctive feature of the first } \\
\text { frame is its explanation of the essen- } \\
\text { ce of both, investment incentives and } \\
\text { cluster initiatives. }\end{array}$ \\
\hline Positive effects & $\begin{array}{l}\text { The second frame emphasizes the } \\
\text { positive effects of both, investment } \\
\text { incentives and cluster initiatives. } \\
\text { These effects include employment, } \\
\text { gross added value, export, multiplier } \\
\text { effects, innovations, human capital } \\
\text { and others. }\end{array}$ \\
\hline
\end{tabular}




\begin{tabular}{|l|l|}
\hline Negative effects & $\begin{array}{l}\text { The third frame emphasizes the ne- } \\
\text { gative effects of both, investment in- } \\
\text { centives and cluster initiatives. These } \\
\text { effects include unmet expectations, } \\
\text { tax losses, rent-seeking behaviour } \\
\text { and others. }\end{array}$ \\
\hline Market distortion & $\begin{array}{l}\text { The distinctive feature of the fourth } \\
\text { frame is market distortion caused by } \\
\text { both, investment incentives and clus- } \\
\text { ter initiatives. Disadvantaged position } \\
\text { of small or local firms is included in } \\
\text { this frame. }\end{array}$ \\
\hline Competition among countries & $\begin{array}{l}\text { The fifth frame is described through } \\
\text { competition among countries caused } \\
\text { by both, investment incentives and } \\
\text { cluster initiatives. }\end{array}$ \\
\hline Lagging regions & $\begin{array}{l}\text { The sixth frame concerns the impact } \\
\text { of both, investment incentives and } \\
\text { cluster initiatives on development of } \\
\text { lagging regions. }\end{array}$ \\
\hline
\end{tabular}

Source: own elaboration based on literature review

\section{DATA AND METHODOLOGY}

The methodology of this paper is based on the agenda-setting and framing concepts. Hence, investment incentives and cluster initiatives were compared according to the frequency of their occurrence in selected mass media sources in the Czech Republic in the periods 2004-2005 and 2011-2012. Subsequently, mass media image of investment incentives and cluster initiatives was evaluated with respect to the frames deductively constructed from literature review (see table 2). The following methodology was used in this regard.

Firstly, a database of mass media articles/news concerning either investment incentives or cluster initiatives in the periods 2004-2005 and 2011-2012 was compiled using search engines by the Media Tenor company. Key words "investment incentives" and "cluster" were searched in the following sources: 
- public Czech Television channels ČT1, ČT2 and ČT24,

- private television channels NOVA and PRIMA TV,

- newspapers Haló noviny, Hospodářské noviny, Lidové Noviny, Mladá Fronta Dnes and Právo.

Additionally, the database of mass media articles/news compiled by search engines was checked by the authors of this paper and the items not relevant for further analysis (e.g., clusters related to other topics such as ornithology, or hardware architecture) were removed. Note that the selected newspapers include mass media with high impact on Czech population from both, left-wing (Haló Noviny and Právo) and right-wing (Hospodářské noviny, Lidové Noviny, and Mladá Fronta Dnes) political ideologies.

Secondly, selected attributes of mass media articles/news were added into the database. Table 3 provides the list of these attributes, including their possible values and sources of information. Note that coding of the mass media articles/ news content by three independent experts was used to assign values of the four attributes - expression/feeling, actors creating the message, framing, territory to each item in the database. Thirdly, information in the database was evaluated using the methods of descriptive (frequency distribution) and inferential (significance testing) statistics.

Table 3: Investment incentives and cluster initiatives - frames

\begin{tabular}{|l|l|l|}
\hline Attributes & Values & Source of information \\
\hline Period of publishing & $\begin{array}{l}\text { a) 2004-2005 } \\
\text { b) 2011-2012 }\end{array}$ & $\begin{array}{l}\text { Media Tenor machine } \\
\text { search }\end{array}$ \\
\hline Type of media source & $\begin{array}{l}\text { a) Public television } \\
\text { chan-nels } \\
\text { b) Private television } \\
\text { channels } \\
\text { c) Left-wing newspa- } \\
\text { pers } \\
\text { d) Right-wing newspa- } \\
\text {-pers }\end{array}$ & $\begin{array}{l}\text { Media Tenor machine } \\
\text { search }\end{array}$ \\
\hline Expression/Feelings* & $\begin{array}{l}\text { a) Positive } \\
\text { b) Negative } \\
\text { c) Neutral }\end{array}$ & $\begin{array}{l}\text { Coding by three inde- } \\
\text { pendent experts }\end{array}$ \\
\hline
\end{tabular}




\begin{tabular}{|l|l|l|}
\hline $\begin{array}{l}\text { Types of actors creating } \\
\text { the message* }\end{array}$ & $\begin{array}{l}\text { a) Economic experts } \\
\text { b) Social and envi- } \\
\text { ronmental experts } \\
\text { c) Public authority } \\
\text { representatives } \\
\text { d) Politicians }\end{array}$ & $\begin{array}{l}\text { Coding by three inde- } \\
\text { pendent experts }\end{array}$ \\
\hline Framing* & See table 2 & $\begin{array}{l}\text { Coding by three inde- } \\
\text { pendent experts }\end{array}$ \\
\hline Territory* & Czech NUTS3 regions & $\begin{array}{l}\text { Coding by three inde- } \\
\text { pendent experts }\end{array}$ \\
\hline
\end{tabular}

* More values may be assigned to an item in the database.

\section{EMPIRICAL RESULTS}

Tables 4 to 9 show first empirical results. Thus, investment incentives were the subject of interest in 501 mass media articles/news in the period 2004-2005 and in 183 mass media articles/news in the period 2011-2012 (see table 4). Cluster initiatives were set on the agenda less frequently - in 119 mass media articles/ news in the period 2004-2005 and in 81 mass media articles/news in the period 2011-2012 (see table 4). The decrease in the number of mass media articles/news dealing with both, investment incentives and cluster initiatives, between the two periods is noteworthy.

Table 4: The number and share of mass media articles/news; investment incentives and cluster initiatives - period of publishing

\begin{tabular}{|l|c|c|c|c|}
\hline \multirow{2}{*}{$\begin{array}{l}\text { Period of } \\
\text { publishing }\end{array}$} & \multicolumn{2}{|c|}{ Investment incentives } & \multicolumn{2}{c|}{ Cluster initiatives } \\
\cline { 2 - 5 } & Number & Share & Number & Share \\
\hline $2004-2005$ & 501 & $73 \%$ & 119 & $60 \%$ \\
\hline $2011-2012$ & 183 & $27 \%$ & 81 & $40 \%$ \\
\hline Total & 684 & $100 \%$ & 200 & $100 \%$ \\
\hline
\end{tabular}

Source: own elaboration; mass media articles/news compiled by the Media Tenor company 
Table 5: The number and share of mass media articles/news; investment incentives and cluster initiatives - type of media source

\begin{tabular}{|l|c|c|c|c|}
\hline \multirow{2}{*}{$\begin{array}{l}\text { Type of me- } \\
\text { dia source }\end{array}$} & \multicolumn{2}{|c|}{ Investment incentives } & \multicolumn{2}{c|}{ Cluster initiatives } \\
\cline { 2 - 5 } & Number & Share & Number & Share \\
\hline $\begin{array}{l}\text { Public televi- } \\
\text { sion channels }\end{array}$ & 76 & $11 \%$ & 11 & $6 \%$ \\
\hline $\begin{array}{l}\text { Private televi- } \\
\text { sion channels }\end{array}$ & 18 & $3 \%$ & 1 & $1 \%$ \\
\hline $\begin{array}{l}\text { Left-wing } \\
\text { newspapers }\end{array}$ & 193 & $28 \%$ & 67 & $33 \%$ \\
\hline $\begin{array}{l}\text { Right-wing } \\
\text { newspapers }\end{array}$ & 397 & $58 \%$ & 121 & $60 \%$ \\
\hline
\end{tabular}

Source: own elaboration; mass media articles/news compiled by the Media Tenor company

Table 5 points out the structure of mass media articles/news dealing with both, investment incentives and cluster initiatives, according to the types of media source. The main difference between investment incentives and cluster initiatives is in the low attention of television channels for the latter instrument. Hence, investment incentives seem to be more interesting topic for public and private television channels than cluster initiatives.

Table 6 points out the structure of mass media articles/news dealing with both, investment incentives and cluster initiatives, according to expression/ feelings of their content. Some interesting insights may be drawn from the table. Firstly, investment incentives are more controversial issue compared with cluster initiatives. Thus, the mass media articles/news evoke both, positive and negative feelings about investment incentives. This is not the case for mass media articles/ news on cluster initiatives that seldom express negative feelings. Moreover, neutral expression is more typical for the mass media articles/news dealing with cluster initiatives. 
Table 6: The number and share of mass media articles/news; investment incentives and cluster initiatives - expression/feelings

\begin{tabular}{|l|c|c|c|c|}
\hline \multirow{2}{*}{$\begin{array}{l}\text { Expression/ } \\
\text { Feelings }\end{array}$} & \multicolumn{2}{|c|}{ Investment incentives } & \multicolumn{2}{c|}{ Cluster initiatives } \\
\cline { 2 - 5 } & Number & Share & Number & Share \\
\hline Positive & 442 & $65 \%$ & 152 & $76 \%$ \\
\hline Negative & 304 & $44 \%$ & 10 & $5 \%$ \\
\hline Neutral & 36 & $5 \%$ & 43 & $22 \%$ \\
\hline
\end{tabular}

Source: own elaboration; mass media articles/news compiled by the Media Tenor company

Table 7 points out the structure of mass media articles/news dealing with both, investment incentives and cluster initiatives, according to the types of actors creating the message. The table reveals that politicians are relatively more involved in the mass media articles/news about investment incentives. On the contrary, economic experts and public authority representatives are relatively more likely to give their opinion in the mass media articles/news about cluster initiatives.

Table 8 points out the structure of mass media articles/news dealing with both, investment incentives and cluster initiatives, according to the frames defined in table 2. Positive effects of both, investment incentives and cluster initiatives are the most common frames of mass media messages related to these two instruments of economic development. However, the frame of positive effects is complemented by other frames, especially by negative effects and market distortion, in the mass media articles/news about investment incentives. This is not the case for cluster initiatives. Generally, the mass media articles/news concerning investment incentives are connected with a more diverse spectrum of frames. 
Table 7: The number and share of mass media articles/news; investment incentives and cluster initiatives - type of actors creating the message

\begin{tabular}{|l|c|c|c|c|}
\hline \multirow{2}{*}{$\begin{array}{l}\text { Type of } \\
\text { actors cre- } \\
\text { ating the } \\
\text { message }\end{array}$} & Number & Share & Number & Share \\
\cline { 2 - 5 } & 143 & $21 \%$ & 61 & $31 \%$ \\
\hline $\begin{array}{l}\text { Economic } \\
\text { experts }\end{array}$ & 26 & $4 \%$ & 12 & $6 \%$ \\
\hline $\begin{array}{l}\text { Social and } \\
\text { environmen- } \\
\text { tal experts }\end{array}$ & 125 & $18 \%$ & 47 & $24 \%$ \\
\hline $\begin{array}{l}\text { Public autho- } \\
\text { rity represen- } \\
\text { tatives }\end{array}$ & 203 & $30 \%$ & 28 & $14 \%$ \\
\hline Politicians & & & & \multicolumn{2}{c|}{ Cluster initiatives } \\
\hline
\end{tabular}

Source: own elaboration; mass media articles/news compiled by the Media Tenor company

Table 8: The number and share of mass media articles/news; investment incentives and cluster initiatives - framing

\begin{tabular}{|l|c|c|c|c|}
\hline \multirow{2}{*}{ Frames } & \multicolumn{2}{|c|}{ Investment incentives } & \multicolumn{2}{c|}{ Cluster initiatives } \\
\cline { 2 - 5 } & Number & Share & Number & Share \\
\hline Explanation & 23 & $3 \%$ & 27 & $14 \%$ \\
\hline $\begin{array}{l}\text { Positive } \\
\text { effects }\end{array}$ & 436 & $64 \%$ & 141 & $71 \%$ \\
\hline $\begin{array}{l}\text { Negative } \\
\text { effects }\end{array}$ & 139 & $20 \%$ & 11 & $6 \%$ \\
\hline $\begin{array}{l}\text { Market dis- } \\
\text { tortion }\end{array}$ & 210 & $31 \%$ & 9 & $5 \%$ \\
\hline $\begin{array}{l}\text { Competition } \\
\text { among coun- } \\
\text { tries }\end{array}$ & 153 & $22 \%$ & 0 & $0 \%$ \\
\hline $\begin{array}{l}\text { Lagging } \\
\text { regions }\end{array}$ & 86 & $13 \%$ & 0 & $0 \%$ \\
\hline
\end{tabular}

Source: own elaboration; mass media articles/news compiled by the Media 
Tenor company

Finally, table 9 points out the structure of mass media articles/news dealing with both, investment incentives and cluster initiatives, according to the territory attribute. Note that the structurally disadvantaged Czech regions - North Moravia and North Bohemia - are the most frequently mentioned territories in the mass media articles/news concerning investment incentives. Moravia-Silesia region is the most typical territory of mass media articles/news on cluster initiatives. Moreover, the territorial focus of these articles/news is rather limited compared with investment incentives.

Table 9: The number and share of mass media articles/news; investment incentives and cluster initiatives - territory

\begin{tabular}{|l|c|c|c|c|}
\hline \multirow{2}{*}{ Territory } & \multicolumn{2}{|c|}{ Investment incentives } & \multicolumn{2}{c|}{ Cluster initiatives } \\
\cline { 2 - 5 } & Number & Share & Number & Share \\
\hline $\begin{array}{l}\text { Moravia-Sile- } \\
\text { sia region }\end{array}$ & 79 & $12 \%$ & 73 & $37 \%$ \\
\hline $\begin{array}{l}\text { Ústecký and } \\
\text { Karlovarský } \\
\text { region }\end{array}$ & 54 & $8 \%$ & 9 & $5 \%$ \\
\hline $\begin{array}{l}\text { Prague and } \\
\text { Central Bohe- } \\
\text { mia region }\end{array}$ & 30 & $4 \%$ & 0 & $0 \%$ \\
\hline $\begin{array}{l}\text { South Mora- } \\
\text { via region }\end{array}$ & 27 & $4 \%$ & 13 & $6 \%$ \\
\hline Other regions & 103 & $15 \%$ & 46 & $23 \%$ \\
\hline
\end{tabular}

Source: own elaboration; mass media articles/news compiled by the Media Tenor company

\section{DISCUSSION}

Empirical results presented in the preceding section indicate that investment incentives are set higher on the agenda of the analyzed mass media sources than cluster initiatives (see table 4 for the number of mass media articles/news). This fact might be explained especially by the differences between the two instruments related to their associations with particular frames (see table 8 and table 10 for statistical significance of differences). Hence, investment incentives seem to be connected with more controversial and colourful stories that attract mass media 
attention. This is further supported by the higher presence of investment incentives in television channels (see table 5 and table 10 for statistical significance of differences) and by the higher politicians' interest (see table 7 and table 10 for statistical significance of differences).

Table 10: Chi-square statistics for the differences between investment incentives and clusters; selected attributes

\begin{tabular}{|l|l|l|l|l|}
\hline Attribute & $\begin{array}{l}\text { Type of } \\
\text { media }\end{array}$ & Expression & $\begin{array}{l}\text { Type of } \\
\text { actors }\end{array}$ & Framing \\
\hline $\begin{array}{l}\text { Chi-square } \\
\text { statistics, } \\
\text { p-value }\end{array}$ & $0,000^{* *}$ & $0,000^{* *}$ & $0,000^{* *}$ & $0.000^{* *}$ \\
\hline
\end{tabular}

** Statistically significant at 0.01 level

Note: type of media without the type "Private television channels"; framing without the frames "Competition among countries" and "Lagging regions" Source: own elaboration; mass media articles/news compiled by the Media Tenor company

On the contrary, cluster initiatives are less frequently dealt with in the analyzed mass media. The media stories concerning cluster initiatives are frequently told by economic experts or public authority representatives who are directly involved in cluster initiatives. Understandably, these stories emphasize positive effects generated by cluster initiatives while the frame of negative effects is suppressed. These findings may be related to the seminal evaluation of the cluster concept provided by Martin and Sunley (2003) who claim that clusters are politically well-accepted theoretical concept because of at least two reasons. Firstly, the cluster concept does not use rigorous academic language but the language of business strategies. It is believed that clusters are beneficial for economic development and the concept could be, therefore, applied practically in all contexts. Secondly, clusters are embedded in recently popular theories of territorial competitiveness and endogenous development. Thus, the emphasis on local firms weakens the strength of more negative frames, including market distortion and competition among countries. Nevertheless, the interest of mass media in cluster initiatives is reduced as well. This may be also observed in the strongly limited territorial focus of mass media articles/news concerning cluster initiatives (see the position of the Moravia-Silesia region in table 9). In some Czech regions, including the capital city of Prague, even no mass media articles/ 
news about cluster initiatives are noticed.

Table 4 indicates the decreasing numbers of mass media articles/news dealing with the both instruments of economic development between the periods 20042005 and 2011-2012. The sharp decrease in the case of investment incentives is noteworthy. Tables 11 and 12 provide additional information about the nature of this decrease. Thus, the number of mass media articles/news is reduced for all frames (see table 11) and types of actors creating the media message (see table 12). However, the frame "positive effects" is relatively more frequently emphasized in the period 2011-2012 while the relative importance of the frame "market distortion" is weakened. Additionally, politicians are relatively less frequent story-tellers in the period 2011-2012 while the importance of economic experts is increasing.

Table 11: The number and share of mass media articles/news dealing with investment incentives in the periods 2004-2005 and 2011-2012 - framing

\begin{tabular}{|l|c|c|c|c|}
\hline \multirow{2}{*}{ Frames } & \multicolumn{2}{|c|}{ 2004-2005 } & \multicolumn{2}{c|}{ 2011-2012 } \\
\cline { 2 - 5 } & Number & Share & Number & Share \\
\hline Explanation & 22 & $4 \%$ & 1 & $1 \%$ \\
\hline $\begin{array}{l}\text { Positive } \\
\text { effects }\end{array}$ & 309 & $62 \%$ & 127 & $69 \%$ \\
\hline $\begin{array}{l}\text { Negative } \\
\text { effects }\end{array}$ & 90 & $18 \%$ & 49 & $27 \%$ \\
\hline $\begin{array}{l}\text { Market dis- } \\
\text { tortion }\end{array}$ & 176 & $35 \%$ & 34 & $19 \%$ \\
\hline $\begin{array}{l}\text { Competition } \\
\text { among coun- } \\
\text { tries }\end{array}$ & 113 & $23 \%$ & 40 & $22 \%$ \\
\hline $\begin{array}{l}\text { Lagging } \\
\text { regions }\end{array}$ & 63 & $13 \%$ & 23 & $13 \%$ \\
\hline
\end{tabular}

Source: own elaboration; mass media articles/news compiled by the Media Tenor company

Tables 13 and 14 add the corresponding information about cluster initiatives. Table 13 reveals that the importance of positive effects of cluster initiatives is further strengthened in the period 2011-2012. The positive stories are often told by economic experts closely connected with cluster initiatives (see table 14). On the contrary, the role of public authority representatives is negligible in the 
period 2011-2012 because the essence and supporting programmes of cluster initiatives are not more explained in mass media articles/news. Altogether, the findings point out some shift of the both instruments of economic development to more positive media image that is less interesting to be set high on the agenda.

Table 12: The number and share of mass media articles/news dealing with investment incentives in the periods 2004-2005 and 2011-2012 - type of actors creating the message

\begin{tabular}{|l|c|c|c|c|}
\hline \multirow{2}{*}{$\begin{array}{l}\text { Type of } \\
\text { actors } \\
\text { creating the } \\
\text { message }\end{array}$} & Number & Share & Number & Share \\
\cline { 2 - 5 } & 91 & $18 \%$ & 52 & $28 \%$ \\
\hline $\begin{array}{l}\text { Economic } \\
\text { experts }\end{array}$ & 22 & $4 \%$ & 4 & $2 \%$ \\
\hline $\begin{array}{l}\text { Social and } \\
\text { environmen- } \\
\text { tal experts }\end{array}$ & 100 & $20 \%$ & 25 & $14 \%$ \\
\hline $\begin{array}{l}\text { Public autho- } \\
\text { rity represen- } \\
\text { tatives }\end{array}$ & 165 & $33 \%$ & 38 & $21 \%$ \\
\hline Politicians &
\end{tabular}

Source: own elaboration; mass media articles/news compiled by the Media Tenor company

Table 13: The number and share of mass media articles/news dealing with cluster initiatives in the periods 2004-2005 and 2011-2012 - framing

\begin{tabular}{|l|c|c|c|c|}
\hline \multirow{2}{*}{ Frames } & \multicolumn{2}{|c|}{ 2004-2005 } & \multicolumn{2}{c|}{ 2011-2012 } \\
\cline { 2 - 5 } & Number & Share & Number & Share \\
\hline Explanation & 26 & $22 \%$ & 1 & $1 \%$ \\
\hline $\begin{array}{l}\text { Positive } \\
\text { effects }\end{array}$ & 77 & $65 \%$ & 64 & $79 \%$ \\
\hline $\begin{array}{l}\text { Negative } \\
\text { effects }\end{array}$ & 9 & $8 \%$ & 2 & $2 \%$ \\
\hline $\begin{array}{l}\text { Market dis- } \\
\text { tortion }\end{array}$ & 3 & $3 \%$ & 6 & $7 \%$ \\
\hline
\end{tabular}




\begin{tabular}{|l|c|c|c|c|}
\hline $\begin{array}{l}\text { Competition } \\
\text { among coun- } \\
\text { tries }\end{array}$ & 0 & $0 \%$ & 0 & $0 \%$ \\
\hline $\begin{array}{l}\text { Lagging } \\
\text { regions }\end{array}$ & 0 & $0 \%$ & 0 & $0 \%$ \\
\hline
\end{tabular}

Source: own elaboration; mass media articles/news compiled by the Media Tenor company

Table 14: The number and share of mass media articles/news dealing with cluster initiatives in the periods 2004-2005 and 2011-2012 - type of actors creating the message

\begin{tabular}{|l|c|c|c|c|}
\hline \multirow{2}{*}{$\begin{array}{l}\text { Type of } \\
\text { actors cre- } \\
\text { ating the } \\
\text { message }\end{array}$} & Number & Share & Number & Share \\
\cline { 2 - 5 } & 22 & $18 \%$ & 39 & $48 \%$ \\
\hline $\begin{array}{l}\text { Economic } \\
\text { experts }\end{array}$ & 6 & $5 \%$ & 6 & $7 \%$ \\
\hline $\begin{array}{l}\text { Social and } \\
\text { environmen- } \\
\text { tal experts }\end{array}$ & 45 & $38 \%$ & 2 & $2 \%$ \\
\hline $\begin{array}{l}\text { Public autho- } \\
\text { rity represen- } \\
\text { tatives }\end{array}$ & 23 & $19 \%$ & 5 & $6 \%$ \\
\hline Politicians & & \multicolumn{2}{|c|}{ 20041-2012 } \\
\hline
\end{tabular}

Source: own elaboration; mass media articles/news compiled by the Media Tenor company

\section{CONCLUSION}

The goal of this paper was twofold. Firstly, two instruments of economic development - investment incentives and cluster initiatives - were compared according to the frequency of their occurrence in selected mass media sources in the Czech Republic in the periods 2004-2005 and 2011-2012. Secondly, mass media image of these two instruments of economic development was evaluated with respect to the frames deductively constructed from literature review. Empirical findings pointed out a rather different media image of the both instruments. Thus, investment incentives were set higher on the agenda of the analyzed mass media 
sources than cluster initiatives when measured by the number of mass media articles/news concerning these two instruments. The stories about investment incentives were more controversial and covered a wider spectrum of frames. Therefore, these stories were more often told by politicians and had much wider spatial origin. On the contrary, the stories dealing with cluster initiatives were typically framed in the positive effects of clusters. These stories were told either by economic experts or by public authority representatives who were closely connected with cluster initiatives. Spatial origin of these stories was rather limited. Even no mass media articles/news about cluster initiatives were related to some Czech regions, including the capital city of Prague. The definitional vagueness, intangible and uncontroversial nature of cluster initiatives restrained their media appeal.

Altogether, the findings of this study may have several political implications. The essence of these implications rests on the assumption that political decisions are influenced by the mass media image of the both instruments of economic development - investment incentives and cluster initiatives. Thus, investment incentives attract more media attention than cluster initiatives. However, politicians should expect more controversies related to investment incentives because it is more difficult to explain positive and negative frames of cluster initiatives in mass media stories. This is caused, among others, by the difficulties to understand and measure direct and indirect outputs and outcomes arising from cluster initiatives. Note that this study provides also useful methodological background for the mass media research focused on instruments of economic development. The frames suggested in table 2 may be taken as general frames in this type of research. Consequently, comparative analyses of various kinds are possible.

Finally, some limitations of this study ought to be mentioned as well. These limitations are closely related to critical comments that are given in the literature concerning the framing concept. Let us mention at least three of them:

- Firstly, it seems that the sociological approach is more common in the framing research compared with the psychological approach. Moreover, specific frames constructed for particular case studies are frequently used in this regard. However, this methodological approach limits the opportunities to generalize research results from high number of case studies - metaapproach (see, e.g., Scheufele \& Iyengar 2014, de Vreese, Peter \& Semetko 2001, Borah 2011, de Vreese 2005). Therefore, it could be desirable to further search for general frames relevant for instruments of economic development. Comparison of mass media image of the theme with other 
themes is then possible.

- Secondly, a limited number of studies combine both, the sociological and psychological approaches to the framing concept. Thus, sociologically based analyses of mass media sources are not accompanied by psychologically based surveys of mass media listeners (see, e.g., de Vreese, Peter \& Semetko 2001, Borah 2011). The knowledge of mass media frames is, consequently, constrained because of the missing link to mass media listeners, such as politicians, voters, minorities and other stakeholders. This could be another fruitful direction of the mass media research dealing with instruments of economic development.

- Thirdly, Scheufele and Iyengar (2014), de Vreese, Peter and Semetko (2001) claim that frame interpretation may be dependent on culture. The framing research is, therefore, culture-sensitive and, consequently, one-country generalization ought to be avoided. This is highly relevant also for the mass media research dealing with instruments of economic development. What are the differences in mass media image of investment incentives and cluster initiatives between Western and Eastern Europe? This is only one relevant research question in this regard.

Further research will by reflect these three limitations in order to, at least partially, fill the research gaps.

\section{REFERENCES}

BATHELT, H, MALMBERG, A \& MASKEL1, P 2004, 'Clusters and knowledge: local buzz, global pipelines and the process of knowledge creation', Progress in Human Geography, vol. 28, no. 1, pp. 31-56.

BLOMSTRÖM, M, KOKKO, A \& MUCCHIELLI, JL 2003 'The economics of foreign direct investment incentives' in Foreign Direct Investment in the Real and Financial Sector of Industrial Countries, Springer, Berlin, pp. 3760.

BORAH, P 2011, 'Conceptual issues in framing theory: a systematic examination of a decade's literature', Journal of Communication, vol. 61, no. 2, pp. 246-263. BROWN, P \& McNaughton, R 2003 'Cluster development programmes: panacea or placebo for promoting SME growth and internationalisation?' in Globalization and Entrepreneurship: Policy and Strategy Perspectives, Edward Elgar, Cheltenham, pp. 106-124.

BURGER, A, JAKLIČ, A \& ROJEC, M 2012, 'The effectiveness of investment incentives: the Slovenian FDI co-financing grant scheme', Post-Communist 
Economies, vol. 24, no. 3, pp. 383-401.

DE VREESE, CH 2005, 'News framing: theory and typology', Information Design Journal + Document Design, vol. 13, no. 1, pp. 51-62.

DE VREESE, CH, Peter, J \& Semetko, HA 2001, 'Framing politics at the launch of the Euro: a cross-national comparative study of frames in the news', Political Communication, vol. 18, no. 2, pp. 107-122.

DICKEN, P 2003, Global Shift. Reshaping the Global Economic Map in the $21^{\text {st }}$ Century, Guilford Press, New York.

ENTMAN, RM 1993, 'Framing: towards clarification of a fractured paradigm', Journal of Communication, vol. 43, no. 4, pp. 51-58.

GINEVIČIUS, R \& ŠIMELYTE, A 2011, 'Government incentives directed towards foreign direct investment: a case of Central and Eastern Europe', Journal of Business Economics and Management, vol. 12, no. 3, pp. 435-450.

GLOBERMAN, S \& SHAPIRO, DM 1999, 'The impact of government policies on foreign direct investment: the Canadian experience', Journal of International Business Studies, vol. 30, no. 3, pp. 513-532.

HÁJEK, O, NOVOSÁK, J \& HOVORKOVÁ, Z 2011, 'Inovace a region: Klastry a regionální inovační systém Zlínského kraje [Innovations and region: clusters and regional innovation system of the Zlínský region]', $E+M$ Ekonomie a management, vol. 14, no. 2, pp. 31-44.

HAYTER, R 1997, The Dynamics of Industrial Location, John Wiley, Chichester.

KAHNEMAN, D \& TVERSKY, A 1984, 'Choices, values, and frames', American Psychologist, vol. 39, no. 4, pp. 341-350.

HORVÁTH, P \& MACHYNIAK, J 2014, 'Electoral behaviour as affected by the media', European Journal of Science and Theology, vol. 10, no. 1, pp. 219-228.

LECHELER, S \& DE VREESE, CH 2012, 'News framing and public opinion: a mediation analysis of framing effects on political attitudes', Journalism \& Mass Communication Quarterly, vol. 89, no. 2, pp. 185-204.

MARTIN, R \& SUNLEY, P 2003, 'Deconstructing clusters: chaotic concept or policy panacea?', Journal of Economic Geography, vol. 3, no. 1, pp. 5-35.

MASKELL, P 2001, 'Towards a knowledge based theory of the geographical cluster', Industrial and Corporate Change, vol. 10, no. 4, pp. 921-943.

MATTHES, J \& Kohring, M 2008, 'The content analysis of media frames: toward improving reliability and validity', Journal of Communication, vol. 58 , no. 2, pp. 258-279.

MORLEY, D \& ROBINS, K 1995, Spaces of Identity. Global Media, Electronic Landscapes, and Cultural Boundaries, Routledge, London.

NAFZIGER, EW 2006, Economic Development, Cambridge University Press, 
Cambridge.

NUUR, C \& LAESTADIUS, S 2010, 'Development in peripheral regions: case studies in Sweden', European Urban and Regional Studies, vol. 17, no. 3, pp. 293-307.

PORTER, M 2000, 'Location, competition, and economic development: local clusters in a global economy', Economic Development Quarterly, vol. 14, no. 1, pp. 15-34.

SCHEUFELE, DA \& IYENGAR, S 2014 'The state of public research: a call for new directions' in The Oxford Handbook of Political Communication Theories, Oxford University Press, Oxford.

SCHEUFELE, DA \& TEWKSBURY, D 2007, 'Framing, agenda setting, and priming: the evolution of three media effects models', Journal of Communication, vol. 57, no. 1, pp. 9-20.

SOROKA, S, MAIONI, A \& MARTIN, P 2013 'What moves public opinion on health care? Individual experiences, systems performance, and media framing', Journal of Health Politics, Policy and Law, vol. 38, no. 5, pp. 893 920.

TÖDTLING, F \& TRIPPL, M 2005, 'One size fits all? Towards a differentiated regional innovation policy approach', Research policy, vol. 34, no. 8, pp. 1203-1219.

WAXELL, A \& MALMBERG, A 2007, 'What is global and what is local in knowledge-generating interaction? The case of the biotech cluster in Uppsala, Sweden', Entrepreneurship \& Regional Development, vol. 19, no. 2, pp. 137159.

WIMMER, RD \& DOMINICK, JR 2011, Mass Media Research. An Introduction, Cengage Learning, Wadswroth. 